\title{
Water Quality Assessment in Terms of Water Quality Index (WQI) Using GIS in Ballia District, Uttar Pradesh, India
}

\author{
Gopal Krishan*, Surjeet Singh, Suman Gurjar, Kumar CP and Ghosh NC \\ National Institute of Hydrology, Roorkee-247 667, Uttarakhand, India
}

\begin{abstract}
In the present study, water quality of groundwater has been assessed in terms of water quality index (WQI) in Ballia district of Uttar Pradesh. Data of 12 groundwater samples each of hand pump and bore well was taken for computing the Water Quality Index using eleven parameters viz. pH, Total Dissolved Solids, Turbidity, Total Hardness, Arsenic, Fluoride, Chloride, Nitrate, Iron, Sulphate and Dissolved Oxygen. The WQI results show that the overall water quality class is 'fair' and water needs treatment.
\end{abstract}

Keywords: Water quality index; Groundwater; Ballia; Uttar Pradesh; Gangetic plains

\section{Introduction}

Groundwater is the largest fresh water resource on the mother earth and quality of groundwater is influenced by the natural/geogenic and/ or anthropogenic sources. Regular monitoring of groundwater quality is essential as it becomes extremely difficult to restore the contaminated groundwater. Water Quality Index (WQI) is an easy and important tool to assess spatial and temporal changes in ground water quality and has been used by various researchers [1-11].

In recent years, excessive use of groundwater has led to its depletion and deterioration of quality in Gangetic basin [12-27] and water quality evaluations have been carried out other parts of India as well [28-36].

Ballia district, the eastern most part of Uttar Pradesh and a part of Central Ganga Plains, occupies an irregular wedge shape tract in interfluvial region of rivers Ganga and Ghaghara. The district has geomorphic units flood plain, newer and older alluvial plains and depth to water level is up to $550 \mathrm{~m}$ in shallow, intermediate and deep aquifers. Groundwater occurs in unconfined, semi-confined and confined aquifers with the presence of arsenic, fluoride and iron more than the permissible limits [37]. Therefore, there is an urgent need to assess the groundwater quality for drinking purpose. In the present study, groundwater quality is assessed for drinking purpose in terms of WQI in Ballia district, Uttar Pradesh.

\section{Study Area}

Ballia district with a total geographical area of $2981 \mathrm{~km}^{2}$, lies between latitude $25^{\circ} 23^{\prime \prime} \mathrm{N}-26^{\circ} 11^{\prime \prime} \mathrm{N}$ and longitude $83^{\circ} 38^{\prime \prime}-84^{\circ} 39^{\prime \prime} \mathrm{E}$ (Figure 1). The district Ballia falls under sub humid climate with the maximum temperature in May and minimum in December. $88 \%$ of the average normal annual rainfall $(983 \mathrm{~mm})$ occurs in monsoon season. The district is an agriculture dominated area and $82.50 \%$ area is irrigated by groundwater. As per the report of CGWB [37], water level varies from 2.42 to $9.90 \mathrm{mbgl}$ in pre-monsoon and from 1.55 to $8.35 \mathrm{mbgl}$ in post monsoon with a fluctuation from 0.85 to 3.65 meters.

\section{Methodology}

The Water Quality Index (WQI) was computed using 11 water quality parameters viz. $\mathrm{pH}$, Total Dissolved Solids, Turbidity, Total Hardness, Arsenic, Fluoride, Chloride, Nitrate, Iron, Sulphate and Dissolved Oxygen of 12 groundwater samples of hand pump and bore hole each (Figure 2) given by Srivastava [38]. As reported by Srivastava [38], water samples have been collected from hand pumps and bore wells after cleaning the bottle with $6 \mathrm{M} \mathrm{HNO}_{3}$ which is followed by washing with double distilled water. The samples were analysed by standard methodology [39]. The methods reported by Singh et al. [7] have been employed where quality rating scale was used assigning the weight values to the selected parameters (Table 1) and have been classified into 5 categories (Table 2).

Geographic information system (GIS) is most effective tool to provide better information for the consumers, policy makers and this helps for taking quick decision. For representing the spatial distribution of sampling locations, the coordinates have been found using the Google Earth satellite view. The interpolation of the water sample values has been done by Inverse Distance Weighting (IDW) interpolation technique in the ArcGIS 9.3 software.

\section{Results and Discussion}

The statistical summary of physico-chemical parameters and WQI variation of 12 samples each taken from hand pump and bore well

\begin{tabular}{|c|c|c|c|}
\hline S No & Parameter & Weight Factor & $\begin{array}{c}\text { Standards (BIS-10500) } \\
(\mathbf{1 9 9 1 )}\end{array}$ \\
\hline 1 & $\mathrm{pH}$ & 1 & $6.5-8.5$ \\
\hline 2 & Total Dissolved Solids (mg/l) & 3 & $500-2000$ \\
\hline 3 & Total Hardness $(\mathrm{mg} / \mathrm{l})$ & 1 & $300-600$ \\
\hline 4 & Turbidity & 1 & $<5$ \\
\hline 5 & DO & 4 & $>8$ \\
\hline 6 & Fluoride & 3 & $<1.5$ \\
\hline 7 & Chloride (mg/l) & 1 & $250-1000$ \\
\hline 8 & Sulphate $(\mathrm{mg} / \mathrm{l})$ & 2 & $25-1000$ \\
\hline 9 & Nitrate & 3 & $<45$ \\
\hline 10 & Iron & 3 & $<0.3$ \\
\hline 11 & Arsenic & 4 & $<0.05$ \\
\hline
\end{tabular}

Table 1: Significance weight and water quality parameters $[7,35,44]$.

*Corresponding author: Gopal Krishan, National Institute of Hydrology, Roorkee-247 667, Uttarakhand, India, Tel: 91-1332-272108; E-mail: drgopal.krishan@gmail.com

Received March 11, 2016; Accepted April 05, 2016; Published April 08, 2016

Citation: Krishan G, Singh S, Gurjar G, Kumar CP, Ghosh NC (2016) Water Quality Assessment in Terms of Water Quality Index (WQI) Using GIS in Ballia District, Uttar Pradesh, India. J Environ Anal Toxicol 6: 366. doi:10.4172/21610525.1000366

Copyright: @ 2016 Krishan G, et al. This is an open-access article distributed under the terms of the Creative Commons Attribution License, which permits unrestricted use, distribution, and reproduction in any medium, provided the original author and source are credited. 


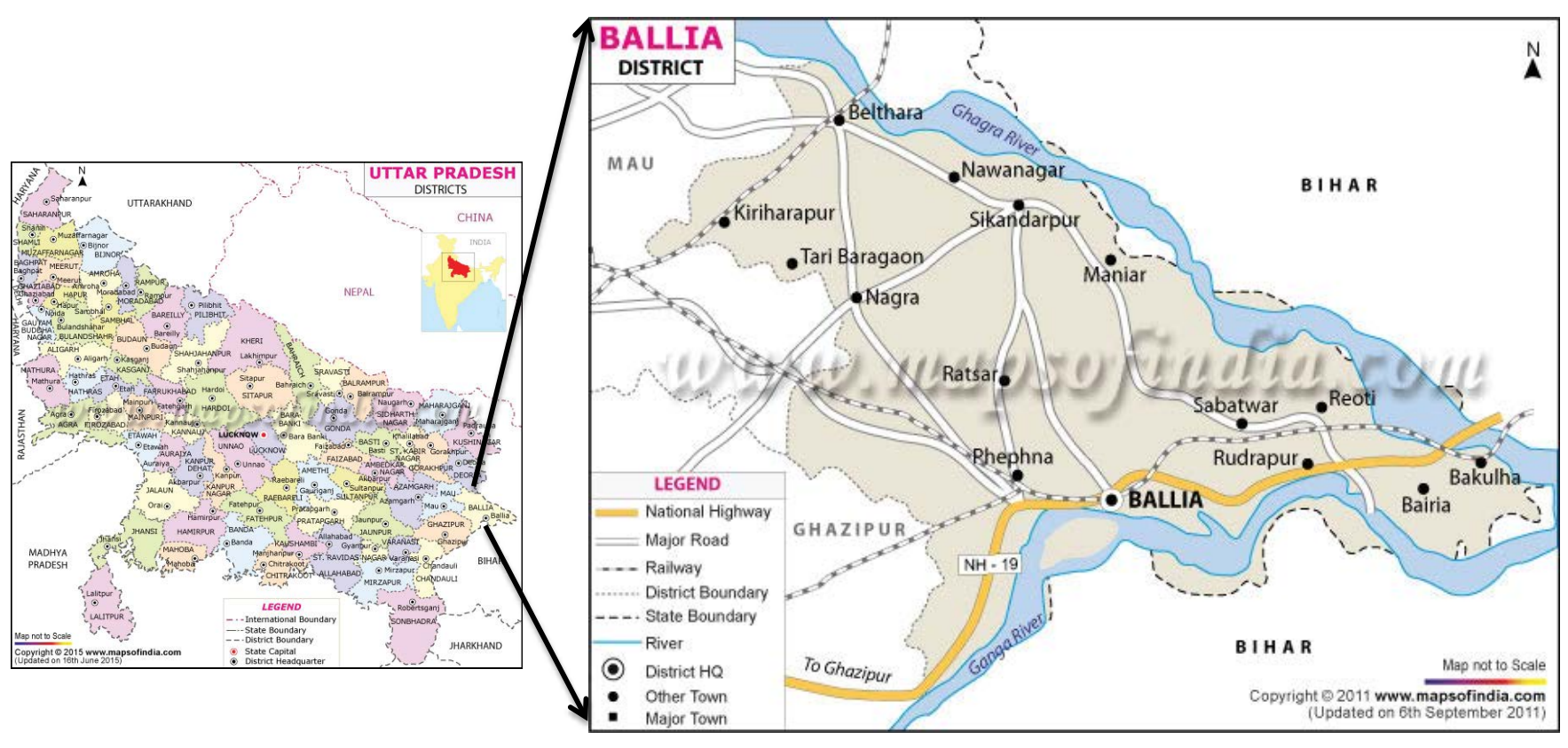

Figure 1: Location map of the study area.

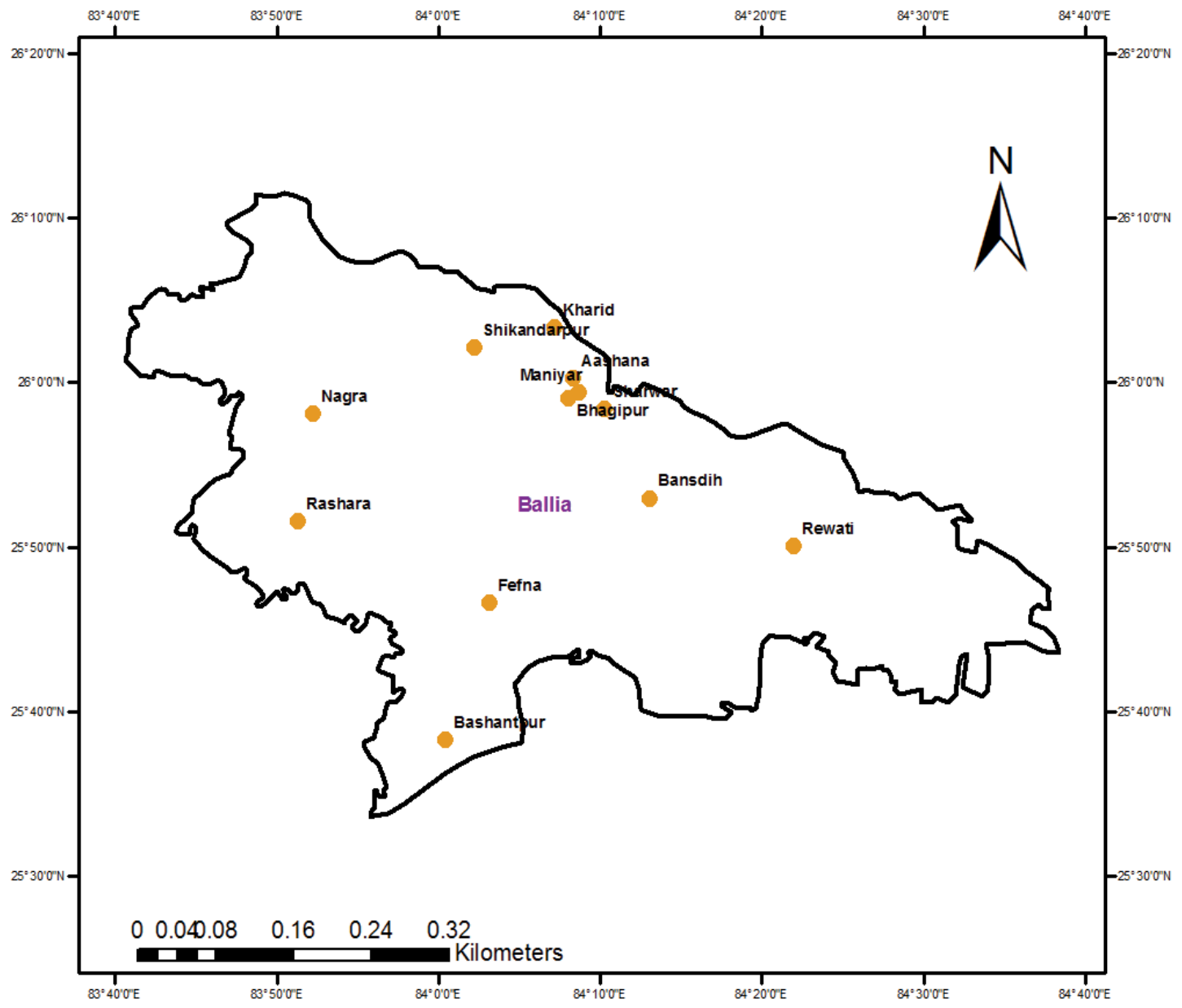

Figure 2: Map showing sampling locations in Ballia District, Uttar Pradesh. 
Citation: Krishan G, Singh S, Gurjar G, Kumar CP, Ghosh NC (2016) Water Quality Assessment in Terms of Water Quality Index (WQI) Using GIS in Ballia District, Uttar Pradesh, India. J Environ Anal Toxicol 6: 366. doi:10.4172/2161-0525.1000366

Page 3 of 6

in Ballia district, Uttar Pradesh is given in Table 3. The Hydrogenion concentration $(\mathrm{pH})$ values are one of the important factors of groundwater and in present study, the value of $\mathrm{pH}$ is found lower than the desired limit (8.5) prescribed by BIS in all the samples.

Total dissolved solids (TDS) in all the samples taken from hand pump varies from 425 to $2856 \mathrm{mg} / \mathrm{l}$ while in the samples taken from bore well, TDS varies from 451 to $1253 \mathrm{mg} / \mathrm{l}$ (Table 3). The higher values of TDS are attributed to application of agricultural fertilizer contributing the higher concentration of ions into the groundwater [40].

Total hardness of water is a measure of dissolved $\mathrm{Ca}$ and $\mathrm{Mg}$ and is expressed as $\left(\mathrm{CaCO}_{3}\right)$ [41] and in the samples taken from hand pump it varies from 211 to $960 \mathrm{mg} / \mathrm{lin}$ the samples taken from bore well it varies from 462 to $2230 \mathrm{mg} / \mathrm{l}$. Accordingly, the groundwater quality in study area is classified as hard water. The turbidity value varies from 1 to 7 NTU with an average value of 4 and 2 to 9 NTU with an average value of 5 in hand pumps and bore wells water, respectively.

Fluorides concentration in groundwater is found to exceed the permissible limit of $1.5 \mathrm{mg} / \mathrm{l}$ in most of the samples and the main sources of fluoride are geogenic/natural like minerals, rocks and sediments. The spatial distribution of fluoride is shown in Figure 3, which indicates fluoride concentration is evenly distributed in whole district. The chloride content in most of the samples taken from hand pump and few samples from bore well have high chloride concentration and some much higher the permissible limit of $200 \mathrm{mg} / \mathrm{l}$. This may be due to its wide distribution in natural environment. The average nitrate value is observed $2.0 \mathrm{mg} / \mathrm{l}$ and $1.9 \mathrm{mg} / \mathrm{l}$, in the samples taken from hand

\begin{tabular}{|c|c|c|}
\hline Class & WQI Value & Status of Water \\
\hline Heavily Polluted & $0-24$ & Unsuitable for All Purposes \\
\hline Poor & $25-49$ & Special Treatment \\
\hline Fair & $50-74$ & $\begin{array}{c}\text { Needs Treatment (Filtration and } \\
\text { Disinfection) }\end{array}$ \\
\hline Good & $75-94$ & Acceptable \\
\hline Excellent & $95-100$ & Pristine Quality \\
\hline
\end{tabular}

Table 2: WQI and corresponding class and status of water quality [7-11]. pump and bore well, respectively which is well within the permissible limit of $45 \mathrm{mg} / \mathrm{l}$.

The average concentrations of iron is found $2.09 \mathrm{mg} / \mathrm{l}$ and 1.04 $\mathrm{mg} / \mathrm{l}$, in the samples taken from hand pump and bore well, respectively exceeding the desirable limit of $0.3 \mathrm{mg} / \mathrm{l}$ [42]. Excess iron in water is mostly accumulated through the weathering of rocks and industrial effluents discharge. The average concentrations of arsenic found 0.17 $\mathrm{mg} / \mathrm{l}$ and $0.18 \mathrm{mg} / \mathrm{l}$, in the samples taken from hand pump and bore well, respectively exceeding the desirable limit of $0.05 \mathrm{mg} / \mathrm{l}$. The spatial distribution of arsenics is shown in Figure 4, which indicates arsenic concentration is evenly distributed in the whole district. The higher arsenic contents may be of geogenic origins in underground alluvial formations.

Dissolved oxygen DO reflects the water quality status of physical and biological processes in water and shows the metabolic balance. DO Levels act as an indicator of status of the water body. The DO average value varies from 11.78 to $21.12 \mathrm{mg} / \mathrm{Land}$ from 15.42 to $26.18 \mathrm{mg} / \mathrm{L}$ in hand pump and bore well water, respectively. According to the data by Srivastava [38], the DO values are surprisingly high and these need further investigation.

The computed WQI values and their spatial distribution for 12 bore wells and hand pumps each in Ballia district, Uttar Pradesh range from 66 to 74 and from 62 to 79, respectively as shown in Figure 5 and can be categorized into "fair" type. The water needs 'Filtration and disinfection' treatment. The reason of low values of WQI may be the higher values of TDS, total hardness, $\mathrm{As}, \mathrm{F}^{-}, \mathrm{Cl}^{-}, \mathrm{HCO}_{3}^{-}, \mathrm{NO}_{3}^{--}$and $\mathrm{SO}_{4}^{--}$. Krishan et al. [8] have found $5 \%$ groundwater samples qualified in the category of 'fair' in Haridwar district of Uttarakhand whereas $21 \%$ of groundwater samples were found unsuitable for drinking purposes in West Bokaro coalfield, India [43,44].

\section{Conclusion}

WQI has been computed based on eleven different quality parameters viz. $\mathrm{pH}$, Total Dissolved Solids, Turbidity, Total Hardness, Arsenic, Fluoride, Chloride, Nitrate, Iron, Sulphate and Dissolved Oxygen to assess the suitability of groundwater for drinking purposes in

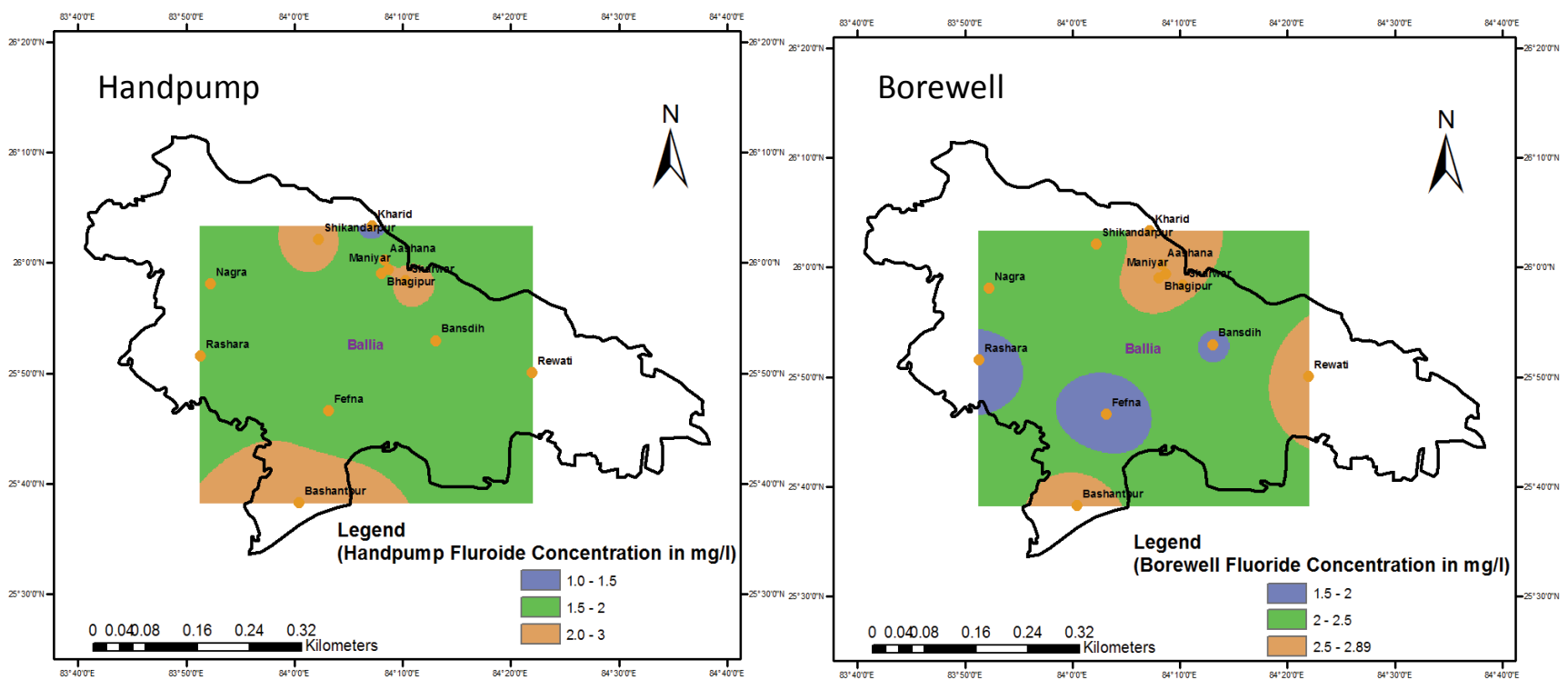

Figure 3: Spatial variation of fluoride in groundwater samples (handpump and borewells) of Ballia District, Uttar Pradesh. 
Citation: Krishan G, Singh S, Gurjar G, Kumar CP, Ghosh NC (2016) Water Quality Assessment in Terms of Water Quality Index (WQI) Using GIS in Ballia District, Uttar Pradesh, India. J Environ Anal Toxicol 6: 366. doi:10.4172/2161-0525.1000366

Page 4 of 6

\begin{tabular}{|c|c|c|c|c|c|c|c|c|c|c|c|c|}
\hline \multirow{2}{*}{ Parameters } & \multirow{2}{*}{$\mathrm{pH}$} & \multirow{2}{*}{$\begin{array}{c}\text { Turbidity } \\
\text { TU }\end{array}$} & \multicolumn{9}{|c|}{$\mathrm{mg} / \mathrm{l}$} & \multirow{2}{*}{ WQI } \\
\hline & & & DO & TDS & As & $\mathrm{Fe}$ & $F^{-}$ & $\mathrm{Cl}^{-}$ & $\mathrm{NO}_{3}^{-}$ & $\mathrm{SO}_{4}^{--}$ & Total Hardness & \\
\hline \multicolumn{12}{|c|}{ Hand pump $(n=12)$} & \\
\hline Minimum & 7.16 & 1 & 12 & 425 & 0.06 & 1.12 & 1.3 & 114.0 & 0.8 & 12.7 & 211 & 66 \\
\hline Maximum & 7.94 & 7 & 21 & 2856 & 0.28 & 2.96 & 2.7 & 535.3 & 2.8 & 34.5 & 960 & 74 \\
\hline Average & 7.45 & 4 & 16 & 1040 & 0.17 & 2.09 & 1.9 & 258.3 & 2.0 & 20.8 & 578 & 69 \\
\hline Std. Deviation & 0.28 & 2 & 3 & 666 & 0.06 & 0.59 & 0.4 & 134.2 & 0.6 & 6.70 & 137 & 3 \\
\hline \multicolumn{12}{|c|}{ Bore well $(n=12)$} & \\
\hline Minimum & 6.48 & 2 & 15 & 451 & 0.07 & 0.12 & 1.5 & 120.0 & 0.7 & 10.2 & 462 & 62 \\
\hline Maximum & 8.02 & 9 & 26 & 1253 & 0.32 & 2.15 & 2.8 & 245.0 & 3.9 & 38.6 & 2230 & 79 \\
\hline Average & 7.47 & 5 & 21 & 864 & 0.18 & 1.04 & 2.4 & 175.3 & 1.9 & 20.7 & 1359 & 67 \\
\hline Std. Deviation & 0.45 & 2 & 3 & 289 & 0.08 & 0.58 & 0.4 & 40.6 & 1.0 & 11.6 & 441 & 5 \\
\hline
\end{tabular}

Table 3: Physico-chemical parameters and WQI of groundwater samples in Ballia District, Uttar Pradesh

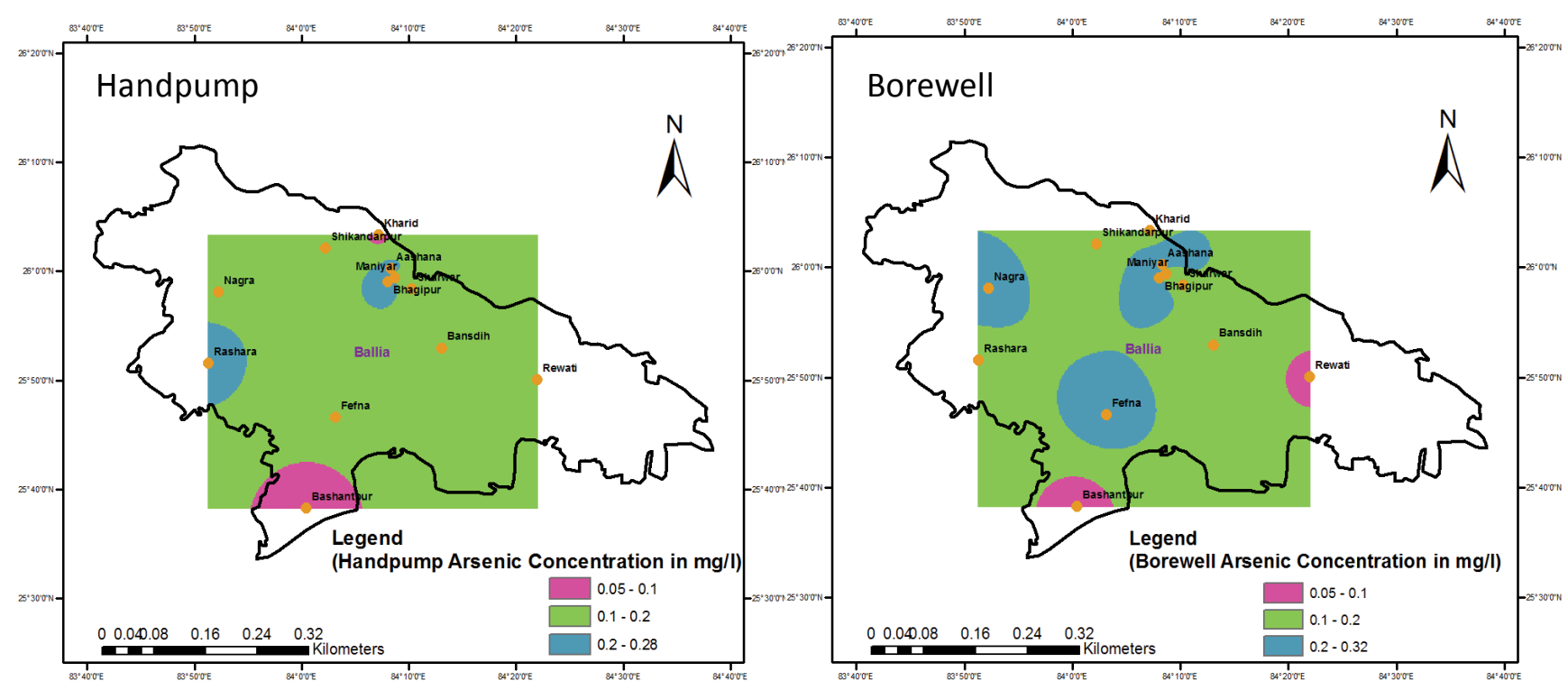

Figure 4: Spatial variation of arsenic in groundwater samples (handpump and borewells) of Ballia District, Uttar Pradesh.

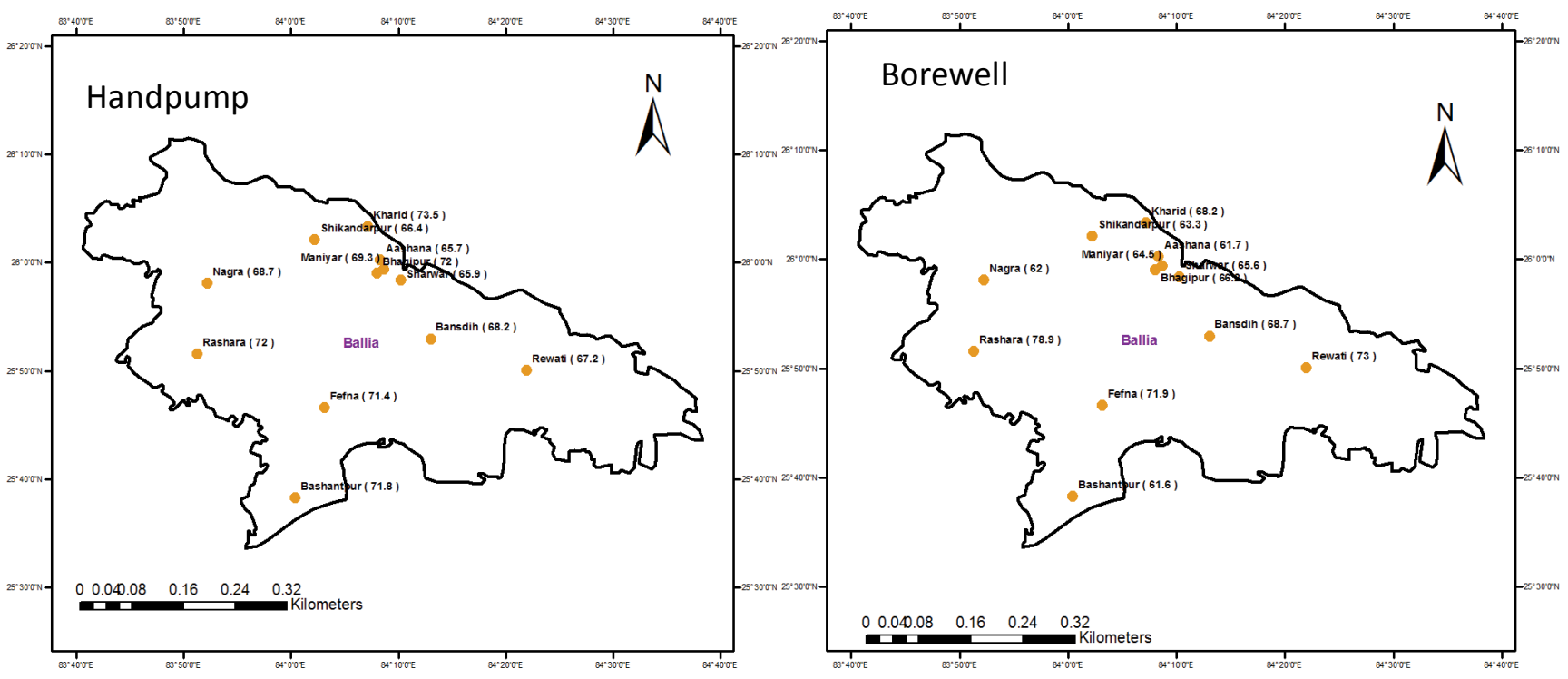

Figure 5: Spatial variation of water quality index in groundwater samples (hand pump and bore wells) in Ballia District, Uttar Pradesh. 
Citation: Krishan G, Singh S, Gurjar G, Kumar CP, Ghosh NC (2016) Water Quality Assessment in Terms of Water Quality Index (WQI) Using GIS in Ballia District, Uttar Pradesh, India. J Environ Anal Toxicol 6: 366. doi:10.4172/2161-0525.1000366

Ballia district, Uttar Pradesh. The WQI show that overall groundwater samples in Ballia district, UP qualify in the 'Fair' category and are not fit as such for drinking. The water needs 'Filtration and disinfection' treatment and then can be used for the drinking purpose. The reason of low values of WQI may be the higher values of TDS, Total Hardness, As, $\mathrm{F}, \mathrm{Cl}^{-}, \mathrm{HCO}_{3}^{-}, \mathrm{NO}_{3}^{--}$and $\mathrm{SO}_{4}^{--}$. Continuous monitoring of groundwater is required by establishing a planned monitoring network in the study area for regular assessment of the WQI which will be useful in proper management of the water resources.

\section{Acknowledgements}

Authors thank Director, National Institute of Hydrology for all necessary support and encouragement.

\section{References}

1. Horton RK (1965) An index number system for rating water quality. Journal of Water Pollution Control Federation 37: 300-306.

2. Brown RM, McClelland NI, Deininger RA, Tozer RG (1970) A water quality index: Do we dare? Water \& Sewage Works 117: 339-343.

3. Soltan ME (1999) Evaluation of groundwater quality in Dakhla Oasis (Egyptian Western Desert). Environmental Monitoring and Assessment 57: 157-168.

4. Stigter TY, Ribeiro L, Dill AMMC (2006) Application of groundwater quality index as an assessment and communication tool in agroenvironmental policies - Two Portuguese case studies. Journal of Hydrology 327: 578-591.

5. Ramakrishnalah CR, Sadashivalah C, Ranganna G (2009) Assessment of water quality index for the groundwater in Tumkur Taluk, Karnataka state, India. E-Journal of chemistry 6: 523-530

6. Rizwan R, Singh G (2010) Assessment of Ground Water Quality Status by Using Water Quality Index Method in Orissa, India. World Applied Sciences Journal 9: 1392-1397.

7. Singh S, Ghosh NC, Krishan G, Galkate R, Thomas T, et al. (2015) Development of an Overall Water Quality Index (OWQI) for Surface Water in Indian Context. Current World Environment 10: 813-822.

8. Krishan G, Singh S, Khanna A, Singh RP, Ghosh NC (2016) Water quality index of groundwater in Haridwar district, Uttarakhand. Water and Energy International 58: 55-58.

9. Krishan G, Kumar CP, Purandara BK, Singh S, Ghosh NC, et al. (2016) Assessment of variation in water quality index (WQI) in north Goa, India. Current World Environment.

10. Krishan G, Singh S, Kumar CP, Gurjar S, Ghosh NC (2016) Assessment of groundwater quality for drinking purpose using water quality index in Muzaffarnagar and Shamli districts, Uttar Pradesh, India. Hydrology: Current Research 7.

11. Krishan G, Singh S, Kumar CP, Garg PK, Gurjar S, et al. (2016) Assessment of water quality index (WQI) of groundwater in Rajkot district, Gujrat, India. Earth Science and Climate Change.

12. Chopra RPS, Krishan G (2014) Analysis of aquifer characteristics and groundwater quality in southwest Punjab, India. Journal of Earth Science and Engineering 4: 597-604.

13. Chopra RPS, Krishan G (2014) Assessment of groundwater quality in Punjab. Journal of Earth Science and Climate Change 5: 243.

14. Krishan G, Rao MS, Loyal RS, Lohani AK, Tuli NK, et al. (2014) Groundwater level analyses of Punjab, India: A quantitative approach. Octa Journal of Environmental Research 2: 221-226.

15. Krishan G, Lapworth DJ, Rao MS, Kumar CP, Smilovic M, et al. (2014) Natura (Baseline) Groundwater Quality In The Bist-Doab Catchment, Punjab, India: A Pilot Study Comparing Shallow and Deep Aquifers. International Journal of Earth Sciences and Engineering 7: 16-26.

16. Krishan G, Rao MS, Purushothaman P, Rawat YS, Kumar CP, et al. (2014) Groundwater Resources in Bist-Doab Region, Punjab, India-an overview. NDC-WWC Journal 3: 5-13

17. Krishan G, Lohani AK, Rao MS, Kumar CP (2014) Prioritization of groundwater monitoring sites using cross-correlation analysis. NDC-WWC Journal 3: 28-31.
18. Krishan G, Singh RP, Takshi KS (2015) Water Level Fluctuation as the Sum of Environmental and Anthropogenic Activities in Southeast, Punjab (India) Journal of Environmental and Analytical Toxicology 5: 298.

19. Krishan G, Singh RP, Khanna A, Singh S, Ghosh NC (2015) Recent groundwate status of groundwater in Haridwar district, Uttarakhand. In: Proceedings of National Seminar on R \& D Perspective for Rejuvenation of River Ganga during 16-17 December, 2015 at NIH, Roorkee, pp: 12-13.

20. Krishan G, Singh S, Sharma A, Sandhu C, Grischek T, et al. (2015) Assessment of river quality for river bank filtration along Yamuna River in AgraMathura districts of Uttar Pradesh. In: Proceedings of National conference on Monitoring and Management of Drinking Water Quality (MMDWQ) \& XXVIII annual conference of National Environment Science Academy during 21-23 December, 2015 at UCOST, Dehradun, p: 48

21. Lapworth DJ, MacDonald AM, Krishan G, Rao MS, Gooddy DC, et al (2015) Groundwater recharge and age-depth profiles of intensively exploited groundwater resources in northwest India. Geophysical Research Letters 42 : 7554-7562.

22. Lapworth DJ, Krishan G, Macdonald AM, Rao MS, Gooddy DC, et al. (2014) Using Environmental Tracers to Understand the Response of Groundwate Resources in Nw India to Sustained Abstraction. In: Proceedings of 41st International Conference of International Association of Hydro-geologist (IAH2014) on Groundwater: Challenges and Strategies during Sep. 18-19, 2014.

23. Lapworth DJ, Krishan G, Rao MS, MacDonald AM (2014) Intensive Groundwate Exploitation in the Punjab - an Evaluation of Resource and Quality Trends. Technical Report. NERC Open Research Archive pp: 34

24. MacDonald AM, Bonsor HC, Taylor R, Shamsudduha M, Burgess WG, et al. (2015) Groundwater Resources in the Indo-Gangetic basin- Resilience to climate change and abstraction. British Geological Survey Open Report, p: 51

25. Macdonald AM, Bonsor HC, Krishan G, Rao MS, Ahmed KM, et al. (2014) Groundwater in the Indo-Gangetic Basin: Evolution of Groundwater Typologies. In: Proceedings of 41 st International Conference of International Association of Hydro-geologist (IAH-2014) on Groundwater: Challenges and Strategies during Sep. 18-19, 2014.

26. Macdonald AM, Bonsor HC, Rao MS, Krishan G, Steenburgen FV, et al. (2013) Groundwater Topologies in the Indo Gangetic Basin. In: Proceedings of International Conference on Advances in Water Resources Development \& Management held at PU, Chandigarh.

27. Rodell M, Velicogna I, Famiglietti JS (2009) Satellite-based estimates of groundwater depletion in India. Nature 460: 999-1002.

28. Gautam SK, Maharana C, Sharma D, Singh AK, Tripathi JK, et al. (2015) Evaluation of groundwater quality in the Chotanagpur plateau region of the Subarnarekha river basin, Jharkhand State, India. Sustainability of Water Quality and Ecology 6: 57-74

29. Krishan G, Rao MS, Kumar CP (2015) Radon Concentration in Groundwater of East Coast of West Bengal, India. Journal of Radioanalytical and Nuclear Chemistry 303: 2221-2225.

30. Krishan G, Rao MS, Kumar CP, Kumar S, Rao MRA (2015) A study on identification of submarine groundwater discharge in northern east coast of India. Aquatic Procedia 4: 3-10.

31. Krishan G, Rao MS, Kumar CP (2014) Estimation of Radon concentration in groundwater of coastal area in Baleshwar district of Odisha, India. Indoor and Built Environment

32. Singh S, Singh C, Kumar K, Gupta R, Mukherjee S (2009) Spatial-Temporal Monitoring of Groundwater Using Multivariate Statistical Techniques in Bareilly District of Uttar Pradesh, India. Journal of Hydrology and Hydromechanics 57: 45-54.

33. Singh SK, Srivastava PK, Gupta M, Mukherjee S (2012) Modeling minera phase change chemistry of groundwater in a rural-urban fringe. Water Sci Technol 66: 1502-1510.

34. Singh SK, Srivastava PK, Pandey AC, Gautam SK (2013) Integrated Assessment of Groundwater Influenced by a Confluence River System: Concurrence with Remote Sensing and Geochemical Modelling. Water Resource Management 27: 4291-4313.

35. Singh SK, Srivastava PK, Singh D, Han D, Gautam SK, et al. (2015) Modeling groundwater quality over a humid subtropical region using numerical indices earth observation datasets, and X-ray diffraction technique: a case study of Allahabad district, India. Environmental Geochemistry and Health 37: 157-180. 
Citation: Krishan G, Singh S, Gurjar G, Kumar CP, Ghosh NC (2016) Water Quality Assessment in Terms of Water Quality Index (WQI) Using GIS in Ballia District, Uttar Pradesh, India. J Environ Anal Toxicol 6: 366. doi:10.4172/2161-0525.1000366

Page 6 of 6

36. Tiwari AK, Singh AK (2014) Hydrogeochemical investigation and groundwater quality assessment of Pratapgarh district, Uttar Pradesh. Journal of the Geological Society of India 83: 329-343.

37. CGWB (2008) [ http://http://cgwb.gov.in/District_Profile/UP/Ballia.pdf ]. Accessed on: 03, March 2016.

38. Srivastava AK (2015) Water Pollution Assessment of Azamgarh Mandal of Ballia District, Uttar Pradesh, India. International Journal on Environmental Sciences 6: 4-8.

39. APHA (1992) Standard Methods for the Examination of Water and Wastewater. American Water and Water works Association and Water Environment Federation.
40. Rao NS (1986) Hydrogeology and hydrogeochemistry of Visakhapatnam.

41. Mitra BK, Sasaki C, Enari K, Matsuyama N (2007) Suitability assessment of shallow groundwater for irrigation in Sand Dune area of Northwest Honshu Island, Japan. International Journal of Agricultural Reserch 2: 518-527.

42. Bureau of Indian Standards (BIS) (2012) IS 10500: 2012.

43. Tiwari AK, Singh PK, Mahato MK (2014) GIS-Based evaluation of water quality index of groundwater resources in West Bokaro coalfield, India. Current World Environment 9: 843-850.

44. Singh S, Krishan G, Ghosh NC, Jaiswal RK, Thomas T, et al. (2015) Designing and Planning of Groundwater Monitoring Network. In: Proceedings of National symposium on Hydrology jointly organized by $\mathrm{IAH}, \mathrm{NIH}$, Roorkee and $\mathrm{CWC}$ New Delhi, India. 